Jerzy Kowalski

\title{
O NIEKTÓRYCH TENDENCJACH ZMIAN W PRAWIE POLSKIM
}

W swym wystąpieniu pragnę wskazać niektóre kierunki modyfikacji prawa polskiego, zachodzące pod wpływem procesu zmian w szeroko rozumianej rzeczywistości społecznej lub też zmian cywilizacyjnych w ogóle. Ponadto warto też wskazać niektóre kwestie rozważane aktualnie na gruncie teorii prawa. Okazuje się bowiem, że rozmaite zagadnienia - zdawałoby się - już dostatecznie zanalizowane, powracaja. Na gruncie prawa konstytucyjnego - dotyczy to na przykład pozycji ustrojowej prezydenta; podziału władz; - do końca lat 90. ub. wieku trwała wielka dyskusja na temat państwa prawa, stymulowana procesem przemian ustrojowych, reorientacja w zakresie filozofii i aksjologii prawa, w zakresie koncepcji prawa (w szczególności zwrot ku koncepcji prawa natury w miejsce prawnopozytywnej koncepcji, i praktyczne implikacje tego zwrotu dla prawa konstytucyjnego i ustawodawstwa zwykłego), a także w związku z pracami nad nową konstytucją. Jeśli w ustawie zasadniczej dokonano wielkiego zwrotu ku idei demokratycznego państwa prawa i konstytucyjnych gwarancji praw człowieka, to po przyjęciu konstytucji owa dyskusja koncentrowała się wokół praktycznych, już politycznych i prawnych konsekwencji tej sytuacji. Dyskusja ta, udokumentowana bodaj dziesiątkami publikacji, zwieńczona została szczególnie ważnymi opracowaniami, i dość tylko przypomnieć - prawem przykładu - publikacje prof. Marii Zmierczak i prof. Sławomiry Wronkowskiej, ale przecież uczestniczyło w niej bardzo wielu luminarzy polskiego prawa, także judykatury.

Tymczasem okazuje się, że był to tylko pewien etap dyskusji - niejako wstępny, w nowej sytuacji polityczno-ustrojowej. Zagadnienie jest nadal aktualne. Świadczy o tym m.in. ogólnopolska konferencja naukowa zorganizowana w bieżącym roku przez Komitet Nauk Prawnych oraz Komitet Nauk Politycznych PAN. Obrady skoncentrowane były wokół trzech głównych zagadnień: 1. Państwo prawa w perspektywie nauk prawnych oraz politologii; 2. Państwo prawa w Rzeczypospolitej Polskiej. Rozwiązania ustrojowe, praktyka polityczna, opinie obywateli; 3. Państwo prawa a przemiany współczesnych mechanizmów władzy. Artykuł sprawozdawczy opublikowany przez Marzenę Kordelę w 7 tegorocznym numerze „Państwa i Prawa” nosi znamienny tytuł: „Spory wokół teorii i praktyki państwa prawa”. Wydany 
przez Wydawnictwo Sejmowe 15 lat temu tom opracowań nosił tytuł: „Polskie dyskusje o państwie prawa".

W tym kontekście można odnotować powrót zagadnienia praworządności.

- Odnośnie do prawa administracyjnego - choć może wydawać się, że jest to problem o dość szczegółowym charakterze - kwestia definicji nadzoru (zwłaszcza w relacji do kategorii ,kontrola”) jest nadal aktualna; ma to związek z reaktywowaniem samorządu terytorialnego, a od pierwszych ustaw tzw. samorządowych (pierwsza była ustawa o samorządzie gminnym) nie maleje ilość prac w szczególności doktorskich, monografii poświęconych ustawodawstwu samorządowemu i właśnie ustaleniu definicji nadzoru - jak na razie - bez dobrego rezultatu. Może być też zaskakujące, że znów podejmuje się rozważania na temat istoty samorządu, choć zręby polskiej teorii samorządu zostały zbudowane już w dwudziestoleciu międzywojennym.

- W filozofii prawa - można by powiedzieć, że o prawie natury powiedziano chyba wszystko. A jednak ten wątek tematyczny powraca w różnych aspektach.

- Podejmowane były - i są - próby konstrukcji nowej dziedziny prawa jak prawo policyjne oraz nowej gałęzi jurysprudencji - jak biojurysprudencja.

- W zakresie prawa medycznego - zaczyna pełniej zarysowywać się problematyka autonomii i praw pacjenta, jego zgody na terapię czy szerzej - na działania medyczne; rozważany jest status prawny proembrionu; z większą mocą rozważane są prawne zagadnienia uporczywej terapii i eutanazji - do niedawna były to problemy właściwe raczej dla innej dziedziny wiedzy, bioetyki.

- W ciaggu kilkunastu lat dokonała się w wielkim zakresie ewolucja prawa polskiego pod wpływem technologii informatycznych, co oddaja już dostatecznie wyraziście tytuły odpowiednich podręczników lub innych dzieł: „Prawo Internetu”; „Prawo komputerowe”; „Prawo karne komputerowe”; „Wpływ Internetu na ewolucję państwa i prawa”. Wszak żyliśmy w okresie, kiedy słowa komputer, sieci komputerowe, Internet, cyberprzestrzeń nie były znane. W następstwie gigantycznego rozwoju technologii cyfrowych i ich praktycznych zastosowań pojawiły się takie idee-koncepcje, jak e-Europa, e-społeczeństwo, e-administracja, e-biznes, i wkrótce idee te zaczęły być także jurydyzowane. W związku z rewolucją technologiczną nowego typu pojawiły się dziesiątki zupełnie nowych kwestii prawnych i odpowiadających im pojęć. Prawem przykładu: elektroniczne czynności prawne i ich skuteczność (oświadczenia woli, wadliwość); podpis elektroniczny, zawarcie umowy w sieci Internet, rodzaje umów; świadczenie usług drogą elek- 
troniczną; ochrona konsumenta w e-umowach; prawo autorskie w społeczeństwie informacyjnym; pieniądz elektroniczny; karnoprawna -ochrona informacji w warunkach jej elektronicznego przetwarzania; ochrona danych osobowych.; cywilnoprawne pojęcie pisemności w społeczeństwie informacyjnym - $\mathrm{i}$ jest to zarazem tytuł artykułu szerzej rozważającego to zagadnienie (,Państwo i Prawo’2009, z. 2).

Początek ewolucji prawa w tym zakresie wyznaczyła ustawa o prawie autorskim i prawach pokrewnych z 4. II. 1994 r., Dz.U. Nr 24, poz. 83 z późn. zm. - był to podstawowy akt prawny wyraźnie regulujący kwestię ochrony programów komputerowych. Większość polskich regulacji prawnych związanych Internetem została wprowadzona do polskiego systemu prawa w związku z procesem harmonizacji z prawem UE, w szczególności z dyrektywami Parlamentu Europejskiego i Rady z lat 1999-2001 w sprawie aspektów prawnych usług w społeczeństwie informacyjnym, zwłaszcza handlu elektronicznego w ramach rynku wewnętrznego, w sprawie wspólnotowych ram w zakresie podpisu elektronicznego, w sprawie praw autorskich w e-społeczeństwie.

- W innym zakresie - należy odnotować jako już trwale ukształtowaną tendencję-odrodzenie studiów romanistycznych. Nie chodzi przy tym tylko o historię prawa rzymskiego jako taką ani o prawo rzymskie jako część wykładu historii prawa, ale o rozwijanie studiów nad jego aktualnym znaczeniem. Studium tego prawa jest pojmowane jako wprowadzenie do współczesnego prawa cywilnego, prywatnego; ujmuje się to prawo jako ius commune Europy i wobec tego oddziałujące na kształtowanie się europejskiej kultury prawnej, a także jako podstawę współczesnej dogmatyki prawniczej. Rozwinęły się studia w szczególnym zakresie: paremie łacińskie w wystapieniach Rzecznika Praw Obywatelskich do SN i TK (zwłaszcza: pacta sunt servanda, lex retro non agit, nullum crimen sine lege, dura lex sed lex, clara non sunt interpretandi). Podobnie - łacińskie paremie w orzecznictwie sądów polskich, zwłaszcza SN i TK. O współczesnym znaczeniu prawa rzymskiego w pełni świadczył program badawczy realizowany w warszawskim ośrodku romanistycznym „Zasady wywodzące się z prawa rzymskiego jako uzasadnienie legalności porządku prawnego w Polsce w świetle orzecznictwa TK, SN i NSA". W programie tym znalazły wyraz na przykład: kwestie skuteczności praw nabytych i problem retroaktywności prawa, koncepcji własności prywatnej w świetle procesów prywatyzacyjnych i reprywatyzacyjnych, pozycja dłużnika w stosunku obligacyjnym z punktu widzenia rzymskiej favor debitoris.

Zarysowała się dyskusja nad przywróceniem pojęcia dobrych obyczajów jako klauzuli generalnej mającej zastąpić ewentualnie zasady współżycia społecznego, a wszak wiadomo, że boni mores było jednym z podstawowych pojęć prawa rzym- 
skiego prywatnego, które przeniknęło do szeroko rozumianego prawa europejskiego. Szkoda, że dyskusja ta przestała być kontynuowana.

Nie sposób wskazać tutaj wszystkie kierunki zmian ustawodawstwa polskiego dokonanych w ciagu kilkunastu ostatnich lat. Nie sposób też scharakteryzować wszystkie kierunki i zakresy dyskusji na gruncie doktryny. Toteż zrozumiałe jest, że proponowany przegląd ma tylko charakter fragmentaryczny, arbitralny, wynikający z osobistego wyboru danych zagadnień.

W najszerszym zakresie dokonała się modyfikacja prawa polskiego w wyniku akcesji naszego kraju do Unii Europejskiej i przejęcia wielu rozwiązań z zakresu prawa międzynarodowego. Proces tych zmian, ujęty już powszechnie zaakceptowaną formułą „europeizacja prawa polskiego", przebiegał (i nadal jest kontynuowany) w dwóch etapach: w okresie przedakcesyjnym (a więc na etapie Stowarzyszenia RP ze Wspólnotami) oraz w okresie poakcesyjnym. Pojęcie „europeizacja prawa" głęboko zakorzeniło się w polszczyźnie i w języku prawniczym, jest terminem powszechnie stosowanym w podręcznikach prawa, w publikacjach o charakterze prawniczym, politologicznym, oficjalno-rządowym itd. Proces implementacji zasad i norm prawa unijnego, zarówno prawa pierwotnego jak i wtórnego oraz proces harmonizacji prawa polskiego i unijnego, ma charakter - można by powiedzieć - totalny, gdyż ogarnął stopniowo wszystkie dziedziny prawa, i w związku z tym w sposób uprawniony określa się: europeizacja polskiego prawa (lub europeizacja prawa krajowego) - karnego, cywilnego, pracy, administracyjnego, prywatnego itd., i co sygnalizują tytuły wielu opracowań z tego zakresu problemowego - powstałych w ostatnich latach. Jest to więc - i będzie nadal - proces ciągły, równoległy do zmian zachodzących w prawie unijnym i w sytuacji członkostwa Polski w Unii Europejskiej. Równocześnie dokonuje się recepcja rozwiązań przyjętych w prawie europejskim (pozaunijnym), w szczególności dotyczy to recepcji ustaleń wielu konwencji międzynarodowych, dorobku prawnego Rady Europy, implementacji ratyfikowanych rozmaitych umów międzynarodowych.

Rozważając przebieg przekształceń polskiego prawa pod wpływem transformacji ustrojowej po 1989 roku, przyjąć można za słuszną konstatację prof. Wiesława Langa, iż „polskie prawo zmienia się ewolucyjnie zarówno na płaszczyźnie aksjologicznej, jak również instytucjonalnej”. (Zob. W. Lang, Aksjologia polskiego systemu prawa w okresie transformacji ustrojowej, (w:) Przemiany polskiego prawa (1989-1999), pod red. E. Kustry, Toruń 2001).

\section{Prawo o cudzoziemcach}

Jednym z przykładów owej ewolucji są przekształcenia jednego z działów prawa publicznego - prawa o cudzoziemcach. Wybieram ten przykład nieprzypadko- 
wo: prawo o cudzoziemcach koresponduje ze skomplikowaną problematyką migracji we współczesnym świecie - jest to problem społeczny, polityczny, ma różne aspekty ekonomiczne; jest to problem ujmowany w traktatach wspólnotowych, ma związki z koncepcją wspólnego jednolitego rynku, z zasadami wolności przepływu osób i usług. W przykładzie tym właściwe są dwa elementy charakterystyczne - jeden to właśnie ów proces ewolucyjny, drugi - to oddziaływanie prawa międzynarodowego - uniwersalnych standardów europejskich, określonych np. w Konwencji o statusie uchodźców, Międzynarodowym Pakcie Praw Politycznych i Obywatelskich. Uwzględnić tu też trzeba wszystkie regulacje międzynarodowe dotyczące wprost praw człowieka - to jest właśnie wspomniana płaszczyzna aksjologiczna. Jednocześnie też prawo to uwzględnia standardy wspólnotowe, wyrażone w prawie wtórnym Unii Europejskiej, uwzględniając tzw. dorobek Schengen (acquis Schengen).

Ewolucja polskiego prawa o cudzoziemcach przebiegała w trzech głównych etapach: 1. nowelizacja ustawy o cudzoziemcach z 29 marca 1963 r. dokonana w 1991 roku; 2. przyjęcie nowej ustawy z 25 czerwca 1997 r.; 3. nowelizacja tej ustawy dokonana 11 kwietnia 2001 roku pod wpływem rozpoczętego procesu negocjacji o członkowstwo RP w UE. Ramy niniejszego wystapienia skłaniają do wskazania tylko kilku wybranych kierunków zmian prawa:

- ustawa z 1997 r. nie była dostosowana do standardów UE, gdyż proces dostosowawczy dopiero się rozpoczynał. W ocenie Komisji Europejskiej z 1999 r. ustawa ta nie uwzględniała dostatecznie prawa pierwotnego i wtórnego regulującego materię wjazdu i pobytu cudzoziemców, choć układ stowarzyszeniowy zawierał w tym zakresie podstawowe zasady; w ślad za tym nastapiło znaczne opóźnienie w wydaniu aktów wykonawczych do ustawy. W wyniku niezbędnej nowelizacji polskie prawo o cudzoziemcach opiera się na normach, które można uznać za jego zasady przewodnie;

- na prymacie prawa międzynarodowego nad ustawą w materii regulowanej przepisami ustawy (art. 1 ust. 2 i 3);

- na zasadach odesłania do prawa międzynarodowego w przedmiocie niektórych norm materialnych (do Konwencji Genewskiej z 1951 r. i Protokołu Nowojorskiego z 1967 r. w odniesieniu do rozdziału 5 ustawy o statusie cudzoziemca);

- oparcie modus operandi na k.p.a. z uwzględnieniem w danych sprawach innych procedur administracyjnych przewidzianych w kpk., kpc.,

- na zasadzie dwuinstancyjności w postępowaniach w sprawach cudzoziemców. 
Przyjęta została szeroka definicja cudzoziemca, która jest identyczna z konstrukcjami jego definicji w prawie innych państw europejskich.

W związku z wieloma uregulowaniami szczegółowymi można określić, że co do zasady na regulacje polskiego prawa o cudzoziemcach (także w przedmiocie wydalenia) miały wpływ zaciągnięte zobowiązania międzynarodowe.

Jednocześnie w latach 1997-2001 zaszły nowe okoliczności „wewnętrzne” $\mathrm{i}$,zewnętrzne" mające wpływ na nowe regulacje prawne. W pierwszym wymiarze - wykształciło się już stanowisko judykatury (TK, SN, NSA) w sprawach położenia prawnego cudzoziemca w Polsce i praktyki administracyjnej w tym zakresie, uwzględniające m.in. kontekst praw człowieka.

W drugim zakresie - zaistniała konieczność uwzględnienia krytycznych uwag Komisji Europejskiej co do polityki wizowej, azylowej i imigracyjnej wchodzącej w skład I Filaru, i w tym także wspólnej polityki wobec państw trzecich. W efekcie Polska, „uszczelniając” granicę, która w niedalekiej przyszłości stałaby się zewnętrzną granicą UE, wypowiedziała umowy o ruchu bezwizowym z 15 państwami. Wystąpiła także konieczność stopniowego realizowania acquis Schengen. Zatem wiele kwestii z tego zakresu uwzględniła nowelizacja z 2001 r. M.in. sprecyzowano i urealniono terminy w postępowaniach w sprawach cudzoziemców, intencjonalnie kładąc kres „niegodziwej praktyce administracyjnej” w tym zakresie (tzn. przeciąganiu w czasie rozpatrzenia sprawy, aż upłynie czas legalnego pobytu, co umożliwia wydalenie cudzoziemca jako już nielegalnego); określono kategorię ,dokument podróży" w miejsce dotychczasowego paszportu; ujednolicono zasady wydawania wizy; zasady pobytu cudzoziemca oparte są na elementach prawa wspólnotowego i zobowiązań RP z umów międzynarodowych; uregulowane zostały zasady łączenia rodzin w związku z umowami międzynarodowymi RP dotyczącymi praw człowieka (prawo do życia w rodzinie, Konwencja o prawach dziecka)), z uwzględnieniem także orzeczeń ETS. W szczególności dodany rozdział 10a uwzględnia założenia dotyczące Systemu Informacyjnego Schengen (SIS) - wprowadzonego przez Porozumienie z Schengen. Uogólniając, można powiedzieć, że polskie prawo o cudzoziemcach nabrało „europejskiego" wymiaru.

\section{Definiowanie „nadzoru” w prawie administracyjnym i prawie gospodarczym publicznym}

Wspomniano już, że od wielu lat ukazują się dzieła, których autorzy definiują „,nadzór”, w tym także w relacji do „kontroli”. Próby zbudowania odpowiednich definicji nie przynoszą spodziewanych efektów, w związku z czym można wskazać kilkanaście definicji, z których znaczna część jest wzajemnie cytowana (na zasadzie powiedzmy - przeglądu definicji), jednakże bez próby ich oceny. Oczywista dąż- 
ność do porządkowania pojęć najbardziej podstawowych w każdej dziedzinie wiedzy motywuje do napisania kolejnej monografii nadzoru.

Mimo jednak wielości określeń, charakterystyk, opisów nadzoru - nie ma przekonania, że dysponujemy definicją nadzoru. Istniejące formuły, uznawane często przez ich autorów za definicje, wskazują tylko różne aspekty nadzoru, nie będąc nimi w istocie rzeczy. I na wskazaniu właśnie takiej tendencji można by poprzestać, jako na konstatacji ściśle określonej sytuacji.

Jednakże ważne jest pytanie, dlaczego owe próby definiowania nie przynoszą efektu? - a odpowiedź może mieć walor bardziej ogólny niż tylko w odniesieniu do prawa administracyjnego. W piśmiennictwie istnieje zatem jedno tylko studium poświęcone tej kwestii. (Roman Sowiński, O definiowaniu „nadzoru” w prawie administracyjnym i prawie gospodarczym publicznym, (w:) Księga Jubileuszowa z okazji 15-lecia Wydziału Prawa i Administracji Uniwersytetu Szczecińskiego, red. Zbigniew Ofiarski, Szczecin 2004, s. 577-514).

Nie ma możliwości streszczenia wywodów Autora, które nawiązują do klasycznej teorii definicji Kazimierza Ajdukiewicza, do teorii nazw Tadeusza Kotarbińskiego. Dlaczego nie ma poprawnej definicji nadzoru? W świetle szczegółowych analiz na gruncie logiki odpowiedź jest nieskomplikowana. Nie będzie takiej definicji, jak długo ich autorzy pomijać będą fundamentalne zasady logiki. Autor w nader szczegółowy sposób omawia kilka definicji, wykazując ich fikcyjność jako definicji właśnie albo mówiąc prościej - że są to definicje pozorne, co niekiedy odnosi się także do autorów - powiedzmy to - poważanych. Można zatem wspomnieć tylko o kilku ustaleniach, nie wnikając w szczegóły.

Zaskoczeniem zapewne będzie zgeneralizowane stwierdzenie, że wszystkie definicje używające zwrotu „,nadzorem jest” lub „nadzór to” są konstrukcjami językowymi pozbawionymi sensu!!! - a taka jest dość powszechna maniera definiowania. Z punktu widzenia statusu językowego słowo „nadzór” bez bliższego dopełnienia w zdaniu jest bezsensowne, a co najmniej niezrozumiałe; jest tak, gdyż zgodnie zresztą z poglądami w literaturze, ,nie ma w instytucji nadzoru jakiejś stałej treści wynikającej jakby z istoty tej instytucji" (L. Bar, Elementy administracyjne w kierowaniu gospodarką narodowa, (w:) Instytucje prawne w gospodarce narodowej (studia prawne), red. L. Bar, Wrocław 1981, s. 93) (natomiast sensowne jest zdanie: nadzór w sferze prawa administracyjnego...).

Ryzykowne - jako definicje - są zdania posługujące się wyrażeniem: ,nadzorowanie to...; „,nadzorowanie prowadzi do...”. Uzasadnienie wiąże się z kategoria „wyrażenia danego języka" i ze względu na określone znaczenie, dzielą się one na terminy i wyrażenia, które nimi nie sa, i te pierwsze mogą być używane tylko jako podmioty lub orzeczniki zdań - i dalej trzeba już odesłać do autora, do dalszych analiz na gruncie gramatyki i logiki. 
W pracach administratywistów nadspodziewanie często spotykamy formuły:

- nadzór zwierzchni polega na korygowaniu działalności [...]- nadzór oznacza [...] prawną możliwość wpływania przez [...]; nadzór polega na porównywaniu zgodności [...]; - nadzór hierarchiczny określić można jako możność jeszcze bardziej skutecznego oddziaływania [...] przez uprzednie wskazówki, przez zmianę dokonanych działań [...];

- są to formuły niewłaściwe: nadzór jest nazwą rzetelną - i nie jest nazwą pozorną. Tymczasem we wspomnianych pracach spotykamy właśnie wypowiedzi, w których ,nadzór” przybiera postać nazwy pozornej - zastępczej (możliwość, możność, korygowaniu, porównywaniu).

Definicje klasyczne, tj. wskazujące rodzaj najbliższy i różnice gatunkowe w przypadku nadzoru są kłopotliwe w konstruowaniu; i autor dopowiada, że ograniczanie się przez dogmatyków prawa do formułowania wyłącznie definicji klasycznych albo zawęża przedmiot ich badań, albo prowadzi do definicji z gruntu niepoprawnych. Istota zagadnienia polega jeszcze na czymś innym: możemy wykazywać stosunki równoważności, nadrzędności, podrzędności, rozłączności i krzyżowania się. Nie możemy natomiast oddać różnego typu stanów (procesów) dynamicznych, a w takich właśnie najczęściej występuje nadzór w administracji i gospodarce. Definicja klasyczna nie obejmuje sytuacji „,iągów działań”, np. w ciągu działań decyzyjnych, który kończy się rozstrzygnięciem nadzorczym i obejmuje (jako warunek sine qua non) m.in. czynności kontroli i następstwa czynności administracyjnych.

Próby definicji nie uwzględniają kwestii „adekwatności definicji”. W tym miejscu znów trzeba by wyjaśniać istotę kwestii, więc tylko wskazać można konsekwencje: wtedy występują błędy w definiowaniu, prowadzące do definicji zbyt szerokich lub zbyt wąskich. W pierwszym wypadku pojawia się definicja przypisująca w warstwie treściowej przedmiotowi definiowanemu cechy, których on nie ma. W drugim przypadku treść definicji nie opisuje (nie uwzględnia) wszystkich cech przedmiotu definiowanego. Przykładem jest definicja bardzo zresztą znanego w swoim czasie autora, w formie: „nadzór polega na możliwości władczego wkroczenia w działalność jednostki nadzorowanej w celu przywrócenia stanu zgodnego z prawem lub zasadniczą linią polityki państwa". W definicji tej występują oba wymienione błędy.

Dla rozdzielania pojęć prawnych nadzoru, kontroli, kierownictwa, pieczy, a więc pojęć znaczeniowo bliskich, konieczne jest postawienie pytania: jaka koncepcja definicji (sprawozdawcza, projektująca, inna możliwa) jest bardziej przydatna?

Autor rozważa jeszcze wiele innych sposobów definiowania nadzoru, na podanych przykładach wypada poprzestać. Trzeba jednak zwrócić uwagę na jedno: nie 
ma zaś definicji legalnej nadzoru, co bardzo jest widoczne w nowej ustawie z ubiegłego roku o wojewodzie i administracji rządowej w województwie. Ustawa ta rozbudowała instytucję nadzoru, rozszerzyła uprawnienia nadzorcze wojewody nad samorządem terytorialnym, ale definicji wspomnianego typu - jest brak.

Widoczna niedogodność braku dostatecznej jasności co do pojęcia nadzoru w prawie administracyjnym i prawie gospodarczym publicznym objawia się w literaturze m.in. wielością stanowisk i zróżnicowaniem ocen w tych samych kwestiach - stwierdza autor tego analitycznego studium - i może wzmagać oczekiwania wyartykułowania przez normodawcę definicji legalnej - a raczej definicji legalnych odnoszących się do poszczególnych typów (rodzajów) nadzoru. Ale jak dotąd - definicji legalnej nadzoru nie ma. Autor opowiada się za ustaleniem jednak legalnej definicji nadzoru. W sytuacji, gdy pojęcie nadzoru używane jest w wielu różnych znaczeniach i zawiera różną treść prawną, byłoby to zasadne i prowadziło do zdecydowania poprawienia relacji komunikacyjnych. Ustawodawca musiałby jednak zdefiniować odrębnie określony typ nadzoru (nadzór x), np. nadzór nad samorządem terytorialnym, nadzór bankowy, nadzór nad przedsiębiorstwem itd.

\section{Prawo policyjne}

Z początkiem lat 90. ub. wieku pojawiła się idea (koncepcja) tworzenia nowego obszaru prawa - prawa policyjnego. W piśmiennictwie wiąże się ją z działalnością naukową i naukowo-organizatorską prof. Wincentego Bednarka, w owym czasie kierownika Zakładu Prawa Policyjnego w Instytucie Nauk Policyjnych. Na podstawie opinii wyrażonych m.in. w dwóch księgach - zbiorach studiów dedykowanych profesorowi, idea ta kształtowała się na kanwie jego głównych zainteresowań naukowych: profilaktyczne zapobieganie przestępczości; organizacja działalności prewencyjnej; wieloaspektowa ochrona bezpieczeństwa i porządku publicznego; organizacja i funkcjonowanie instytucji policyjnych w Polsce i na świecie; różnorodne organizacyjno-prawne aspekty pracy Policji i innych służb mundurowych. Uogólnić można - były to zagadnienia ustroju specjalnych organów administracji publicznej. We wspomnianych księgach pamiątkowych stwierdzano: ,zasługą Profesora Wincentego Bednarka pozostaje koncepcyjny i projektodawczy udział w tworzeniu na początku lat 90. polskiego prawa policyjnego i normatywnych podstaw szkolnictwa policyjnego". Prace w tym zakresie zostały jednak przerwane wskutek okoliczności niezależnych od osoby profesora i ostatecznie nowa, odrębna dziedzina prawa nie wykrystalizowała się, choć jej nazwa zachowała się w piśmiennictwie. Trudno jest przy tym wskazać opracowanie, które by wyraźnie konceptualizowało tę ideę, prezentowało teoretyczne podstawy w zamyśle nowej dziedziny prawa. 


\section{Biojurysprudencja}

Inaczej przedstawia się zagadnienie koncepcji prof. Romana Tokarczyka, który od połowy lat 90 . formułuje założenia - w swym rozumieniu - nowej dziedziny jurysprudencji i określa ją jako „biojurysprudencja”. Równolegle wprowadza on nowe pojęcie „,bioprawo”. W swych publikacjach (także w języku angielskim) ustala treść tych pojęć, określa ich relacje. W przeświadczeniu autora biojurysprudencja jest tak ważnym nowym nurtem we współczesnej teorii prawa, iż „uwzględniając potrzeby XXI wieku, kładzie podwaliny myślowe pod praktyki tworzenia i stosowania prawa". Przeświadczenie to wprost znajduje wyraz w tytule jednego z ostatnich jego dzieł: „Biojurysprudencja. Podstawy prawa dla XXI wieku” (Lublin 2008, Wydawnictwo UMCS; także edycja angielskojęzyczna). Generalne założenia swej koncepcji prof. Roman Tokarczyk sformułował w książce „Biojurysprudencja. Nowy nurt jurysprudencji” (1997). Kolejne edycje dzieła, aktualizowane i rozszerzane o nowe wątki, ukazywały się pod tytułem „Prawa narodzin, życia i śmierci. Podstawy biojurysprudencji” (do 2006 roku 8 wznowień). Sygnalizowana koncepcja, upowszechniana w kraju i za granicą, spotyka się ze zróżnicowanym przyjęciem: od akceptacji po wyraźny sceptycyzm. Tak np. prof. Stefan Symotiuk stwierdza we Wprowadzeniu do edycji z 2006 roku, uznając za samym autorem, iż biojurysprudencja stała się rzeczywistością z „centrum” dyscyplin prawniczych i ma już rację bytu wśród uznanych dyscyplin i nurtów myślenia prawniczego. Od siebie określa, że jeśli tradycyjne zagadnienia bioetyki sytuują się na pograniczu wiedzy filozoficznej i przyrodniczej, „te same problemy na gruncie biojurysprudencji nabierają wyraźnej wymierności i przejrzystości - tu konkret i abstrakcja, wartość i fakt, łączą się w sposób właściwy „nauce”. I jeszcze: ,jakkolwiek ustalimy miejsce nowego nurtu wśród dyscyplin prawoznawstwa, to wypada zgodzić się, że biojurysprudencja stoi w samym rdzeniu ,paradygmatu prawa” i swoim wyodrębnieniem się jako samodzielnej dziedziny, dowodzi ona duchowej mocy prawa [...] jej przyszłość zapowiada się ciekawie i bogato". Można jednak dowodzić, że w gruncie rzeczy problematyka ta mieści się w podstawowych nurtach rozważań prowadzonych w ramach współczesnej bioetyki, nie wnosząc doń nowych elementów.

Sam autor uważa, że przedmiot biojurysprudencji dotyka wielu dyscyplin wiedzy zainteresowanych rozległą i trudną problematyką narodzin, życia i śmierci. Nowość polega na tym, że jest to próba scalenia i jednolitego ujęcia rozproszonej wiedzy na gruncie nowego nurtu jurysprudencji, nazwanego właśnie biojurysprudencją. Sądzi, że ten nowy nurt „odsłania najgłębszy sens prawa - bioprawa; że sami prawnicy są w stanie nie tylko dostrzegać, ale i wyjaśniać ów najgłębszy sens prawa". I zdecydowanie wyraża pogląd wobec stanowisk sceptycznych: „Mimowolnie uwłaczają samodzielności myślowej prawników ci spośród nich, którzy treści należące wprost do biojurysprudencji przypisują innym dyscyplinom naukowym - bioety- 
ce, biomedycynie, biotechnologii”. Wyraża nadzieję, że przyjdzie czas, w którym nie tylko wszyscy prawnicy przyznają, że wśród ogółu znanych praw prawo pierwszeństwa istnienia, ochrony i poprawiania jakości życia, co upowszechnia biojurysprudencja, było, jest i będzie bezsporne". Wobec perspektyw - mówiąc najogólniej - nasilenia się tendencji tworzenia życia sztucznego, zagrożenia życia naturalnego człowieka życiem sztucznym, co stanowi wielkie wyzwanie dla nauk prawnych, zagadnienia te podejmuje biojurysprudencja. Jej generalną koncepcję wywodzi autor z prawa natury i uznaje, że w centrum zainteresowań owego nowego nurtu znajduje się ochrona życia. Idei przewodnich tej koncepcji jest wiele - mają one liczne uwikłania w innych dyscyplinach wiedzy. Wszystkie jednak ogniskują się w przeświadczeniu - i zarazem postulacie autora, jeśli to tak można oddać w skrócie - iż nowa dyscyplina wiedzy prawniczej w kompleksowy sposób ujmie zagadnienia życia, co ostatecznie ma wpłynąć na proces tworzenia prawa.

\section{Praworządność}

Zagadnienie praworządności powróciło w nowym kontekście. Na przełomie lat 80 . i 90. ub. wieku, w związku z początkiem przemian ustrojowych, pojęcie to niemal zostało zarzucone, w nauce prawa konstytucyjnego nie przywiązywano już do niego (jak i do problematyki praworządności) nadmiernego znaczenia. Oba pojęcia (praworządność i państwo praworządne) obarczone były nie najlepszą tradycją prawno-polityczna, były to charakterystyczne terminy dla socjalistycznej teorii prawa i państwa. Praworządność i związana $z$ nią zasada legalizmu były pojmowane jako jedne z podstawowych zasad ustroju Polskiej Rzeczypospolitej Ludowej i problematyka ta wyparła całkowicie zagadnienie państwa prawnego $\mathrm{z}$ jego formalnymi i instytucjonalnymi gwarancjami przestrzegania prawa. W nowej konstytucji RP z 1997 roku zrezygnowano z tego pojęcia i zastąpiono je pojęciem państwa prawnego. Obecnie zagadnieniu praworządności nadaje się większe znaczenie, uznając, że problematyka ta zarówno w aspekcie materialnym, jak i formalnym ma wręcz charakter fundamentalny, wraz z przeświadczeniem, że wymaga ciagłego monitorowania w układzie założenia a rzeczywistość. Zagadnienie praworządności powiązane jest wprost z ideą rządów prawa, w rozumieniu, że organy władzy publicznej nie mogą działać arbitralnie, muszą respektować wiążące je przepisy prawa krajowego i międzynarodowego. Dla państwa prawa jest to problematyka niezmiernie ważna z punktu widzenia funkcjonowania struktur państwowych, jak też jest istotna dla każdego obywatela. Takie podstawowe przeświadczenia przyświecały na przykład piętnastym Ogólnopolskim Dniom Prawniczym (Bydgoszcz 2009) pod hasłem „Praworządność i jej granice”. W piśmiennictwie akcentuje się aksjologiczny wymiar tej problematyki, zwraca się uwagę na gwarancje praworządności. Następuje pewne przesunięcie akcentów w jej ujmowaniu. Choć istotne są oba aspekty 
- formalny i materialny, to zwłaszcza drugi aspekt wiąże się z tym, iż nie może tu być obojętna treść prawa, która powinna podlegać odpowiedniemu wartościowaniu. Istotne jest też, czy mimo szybko zachodzących w prawie zmianach systemowych, a także w ustawodawstwie zwykłym, są chronione i w jakim zakresie nabyte wcześniej konstytucyjne prawa i wolności. Inaczej mówiąc - wyraźniej zarysowuje się problematyka konstytucyjnej ochrony praw w sukcesywnie następujących po sobie zmianach stanu prawnego. W takim też kontekście rozpatrywana w piśmiennictwie jest linia orzecznicza TK w zakresie ochrony praw słusznie nabytych. W orzecznictwie Trybunału ochrona tych praw ujmowana jest jako element zasady zaufania do państwa i zasady zaufania do stanowionego przezeń prawa, a obie te zasady należą do zasad szczegółowych wynikających z konstytucyjnej zasady demokratycznego państwa prawnego. Akcentuje się, że w orzecznictwie TK ochrona praw słusznie nabytych dotyczy tak osób fizycznych, jak i innych podmiotów prawa publicznego. Co więcej, występuje konstytucyjna ochrona - obok praw słusznie nabytych - także ekspektatyw i ich ochrona odbywa się na takich samych zasadach jak ochrona praw słusznie nabytych.

W obszarze zagadnień oznaczonym pojęciem ,praworządność” zwraca uwage kwestia realizacji orzeczeń TK odnośnie do niekonstytucyjności danych regulacji prawnych, w związku z czym następuje utrata ich mocy obowiązującej. Trybunał Konstytucyjny występuje tutaj jako „negatywny ustawodawca”, nie mając kompetencji prawotwórczych. Rozstrzygnięcia TK o derogacji rozwiązań prawnych w wyniku stwierdzenia ich niekonstytucyjności wymagają zatem działań „pozytywnego ustawodawcy" dla przywrócenia stanu konstytucyjności prawa. W tym zakresie jednak kształtuje się niekorzystna sytuacja - narasta liczba niewykonanych orzeczeń TK, utrzymują się poważne uchybienia i luki w systemie prawa, tak dalece, że - jak to określono - pojawia się groźba jego anarchizacji. Zatem trzeba zwrócić uwagę na inicjatywę Senatu RP z 2007 roku, mającą temu zapobiec. Na mocy odpowiedniej uchwały Senatu do jego Regulaminu wprowadzony został nowy dział IXa zatytułowany „Wykonywanie orzeczeń Trybunału Konstytucyjnego”. Określono procedurę podejmowania przez organy Senatu czynności mających doprowadzić do realizacji orzeczeń TK. Chodzi tu o wszczęcie postępowania w sprawie inicjatywy ustawodawczej i wniesienia do Sejmu projektu ustawy, uwzględniającej konsekwencje powstałe dla systemu prawa po wydaniu orzeczenia przez Trybunał, by przywrócić stan konstytucyjności. Problemem jest jednak przede wszystkim to, że zgodnie z konstytucją inicjatywą ustawodawczą dysponuje nie tylko Senat, ale posłowie, prezydent, rada ministrów, a w kontekście owej konstytucyjności te uprawnienia nie są należycie wykorzystywane, a przecież podejmowanie działań zmierzających do realizacji orzeczeń TK jest konstytucyjnym obowiązkiem wszystkich organów władzy publicznej. Okazuje się więc, że problematyka praworządności ma bardziej złożone wymiary niż tylko formalny i materialny, w tym także dynamiczny. 


\section{Samorząd}

W ogromnym piśmiennictwie poświęconym samorządom i odpowiedniemu ustawodawstwu pojawia się nowy wątek - podstaw aksjologicznych idei samorządności i prawa ją wyrażającego. Znajduje to odzwierciedlenie w tezie, iż „zrozumienie podstaw aksjologicznych - a nawet głębszych, humanistycznych - daje nam pełną szansę zrozumienia celów i funkcji takiej instytucji prawnej, jaką jest samorząd. Umożliwia też weryfikację regulacji prawnych dotyczących samorządu w aspekcie uszanowania idei i wartości inicjalnych". Tak więc formułuje się, że idea samorządności zakorzeniona jest w prawie człowieka do decydowania o sobie samym (prawo do samodecydowania), rozwijana na gruncie współczesnych neoliberalnych koncepcji filozoficznych (dość wspomnieć koncepcje F.A. Hayeka liberalizmu ewolucyjnego, czy M. Friedmana - koncepcja „ekonomii pozytywnej”). Koncepcje te eksponują wolność jednostki, wyrażającą się w prawie do samodecydowania. $\mathrm{Na}$ innym biegunie myśli filozoficznej prawo do samodecydowania ujęte jest w myśli społecznej Kościoła katolickiego: odrzucając neoliberalizm, akcentuje w to miejsce idee personalizmu chrześcijańskiego: człowiek jest osobą wolna, ale wolność ta nie jest nieograniczona i jej granice wyznacza najogólniej mówiąc - Dekalog.

Prawo do decydowania o sobie jest w pewnej części cedowane na korporacje publicznoprawne, nazywane samorządami (terytorialnymi, zawodowymi, gospodarczymi). Zatem wśród różnych cech, jakie można przypisać samorządowi, samodzielność ma szczególne znaczenie i może być rozpatrywana w różnych aspektach - prawnym, ekonomicznym, politycznym, socjologicznym. Generalizując - samodzielność jest elementem konstrukcyjnym jego definicji. Jest to cecha podnoszona do rangi istoty samorządu, powinna być uznawana za jedną z zasad samorządu terytorialnego. W naszym systemie prawnym jest to także zasada konstytucyjna; choć nie została zdefiniowana w konstytucji RP, ale daje wyprowadzić się z treści norm konstytucyjnych jako efekt działań interpretacyjnych ( $\mathrm{z}$ art. 16 ust. 2, art. 165 ust. 2). Uwzględnić tu należy także odpowiednie wyroki TK (np. z 4 maja 1998 K 38/97 - OTK ZU 1998, nr 3, poz. 31, s. 173).

Co do teorii samorządu - obok klasycznych (naturalistyczna, państwowa, polityczna) - aktualnie kształtuje się nowa, uniwersalistyczna. Novum polega na tym, że akcentuje ona nie tyle charakter i treść wzajemnych stosunków pomiędzy państwem a samorządem terytorialnym, ile zakres implementowania treści i charakteru norm prawnych o charakterze ponadpaństwowym (ponadnarodowym). Chodzi tu w pierwszym rzędzie o wiązanie się państw normami o charakterze ponadpaństwowym (uniwersalnym). Teoria ta znalazła wyraz w aktach prawnych o zasięgu europejskim (np. Europejska Karta Samorządu Terytorialnego, Europejska Konwencja Ramowa o Współpracy Transgranicznej między Wspólnotami i Władzami Terytorialnymi, Europejska Karta Samorządu Regionalnego) - a także o zasięgu świato- 
wym (Światowa Deklaracja Samorządu Terytorialnego). Zasady ustalone w tych dokumentach przenikają także do ustawodawstwa polskiego.

W świetle tych koncepcji, które tu zasygnalizowano tylko wybiórczo i ogólnie, zagadnienie nadzoru nad działalnością samorządu nabiera innego wymiaru. Poza dyskusją pozostaje konieczność nadzoru nad działalnością samorządu. Jednakże tworzeniu i stosowaniu prawa z zakresu nadzoru towarzyszyć winno przede wszystkim przeświadczenie o nadrzędności zasady samodzielności względem nadzoru. O ile bowiem samodzielność jest wartością (której ochrona jest konstytucjonalizowana) i postrzegana jako istota samorządu, o tyle nadzór wartością samą w sobie nie jest. Nie jest on także w administracji celem samym w sobie. Jest natomiast instrumentem służącym osiąganiu pewnych celów prawem określonych. Powstaje więc ,pole koegzystencji” samodzielności i nadzoru i w związku z tym konieczne jest wyznaczenie granicy samodzielności samorządu i ingerencji ze strony organów nadzoru. Należytemu konstruowaniu nadzoru nad samorządem winno towarzyszyć przeświadczenie, że ,zły nadzór” może deformować czy wręcz niweczyć ideę (wartość) samodzielności. Może to dokonywać się na etapie tworzenia prawa (gdy ustawodawca ,uprzywilejowuje” organy nadzoru, bezpodstawnie wyposażając je w zbyt szerokie kompetencje) albo na etapie stosowania prawa (nieracjonalne, nieuzasadnione, nieproporcjonalne czy też nadto intensywne sięganie do nadzoru). Na marginesie tych kwestii można dodać, że np. najnowsza ustawà o wojewodzie i administracji rządowej w województwie z 2009 roku wzmocniła instytucję nadzoru wojewody nad samorządem terytorialnym. Generalizując - z regulacji prawnych o charakterze międzynarodowym wyłania się obraz samorządu terytorialnego, dla którego samodzielność ma podstawowe znaczenie, a jej ograniczenia mogą być dokonywane jedynie w wypadkach przewidzianych prawem w konstytucjach lub ustawach, na podstawie (co do zasady) kryterium legalności i w zgodzie z regułą proporcjonalności interwencji. Kończąc ten wątek samorządu i jego pojmowania, można refleksyjnie zwrócić uwagę, że problematyka bardziej „subtelnego" - jeśli tak można powiedzieć - traktowania nadzoru powróciła po przeszło 70 latach, kiedy to w pracy z 1936 roku „Rozważania ideologiczne i programowe na temat samorządu" jej autor, M. Jaroszyński, w wątku możliwości zniszczenia idei samodzielności, pisał: „,nadzór [...] jest bardzo delikatnym instrumentem, którym tylko bardzo ostrożnie można operować. Użyty nieostrożnie może odebrać samorządowi cały jego państwowy i społeczny sens, mianowicie - samodzielność".

Z konieczności ograniczyłem się do zasygnalizowania tylko wybranych kwestii. Mamy jednak poczucie, że system prawa polskiego niezmiennie ewoluuje i jest to proces niepowstrzymany. I zapewne nie w sposób w pełni dostateczny, ale reaguje na nowe problemy, które kształtują się w życiu społecznym, zarówno pod wpływem czynników zewnętrznych, jak i wewnętrznych - krajowych. 